\title{
A influência da geodiversidade da região da Serra do Cabral (norte de MG) na variabilidade morfossedimentar do Córrego da Gameleira
}

\author{
Cláudio Eduardo Lana ${ }^{1}$ \& Paulo de Tarso Amorim Castro ${ }^{2}$
}

\begin{abstract}
Resumo A análise de modelos de declividade da bacia do rio Jequitaí, gerados a partir de imagens SRTM, em busca de zonas de retenção de sedimentos, permitiu que fosse identificada uma área de drenagem anômala na porção oriental da bacia, entre as serras do Espinhaço e do Cabral. A anomalia em questão se traduz em uma sucessão de vales com sessão transversal e padrões de sedimentação bastante variáveis, ao longo de um segmento relativamente curto do córrego da Gameleira. O contexto litoestrutural da região, incluindo deformações cenozoicas, sugere que a evolução do sistema fluvial estudado está diretamente relacionada a variações locais na composição das rochas que constituem o substrato do canal, representado neste caso por uma única unidade litoestratigráfica (Subgrupo Paraopeba). Além disso, o basculamento para norte da porção meridional da bacia, em direção ao "graben do Jequitá́", contribui com o cenário morfossedimentar. Perfis de fácies sedimentares indicam que a área em apreço já esteve sobreposta por leques aluviais provenientes, provavelmente, da serra do Espinhaço. Os resultados demonstram que segmentos fluviais não encaixados podem ser erroneamente classificados como agradacionais. Na área investigada as características morfossedimentares são de difícil predição, tendo em vista que refletem particularidades da geodiversidade local.
\end{abstract}

Palavras-chave: Anomalia de drenagem, controle litoestrutural, geodiversidade.

\begin{abstract}
The influence of the geodiversity of Cabral Range region (northern Minas Gerais) on the Gameleira Stream morphologic variability. SRTM-derived slope models were analyzed to find sediment storage zones in Jequitaí hydrographic basin. Those data provided the identification of an anomalous drainage site located at Jequitaí basin's eastern portion between Espinhaço and Cabral ranges. Some contrasts of sedimentation pattern and valley cross-section along a short segment of Gameleira stream are good examples of these anomalies. Regional litho-structural analysis, including Cenozoic deformations, suggests that local variations of the Paraopeba Subgroup components are the main responsible for the observed fluvial system evolution. In addition, the northward tilting of Jequitaí basin's southern portion, in the Jequitaí graben direction, increase the anomalous litho-structural effects. Log profiles suggest that alluvial fans coming probably from Espinhaço range covered the research sites. This work shows that some non-erosive fluvial segments can be mistakenly explained as agradational. The studied segment presents morpho-sedimentary attributes that reflect the local geodiversity setting, where predictions are very difficult.
\end{abstract}

Keywords: drainage anomaly, litho-structural control, geodiversity.

INTRODUÇÃO Os sistemas fluviais têm sido investigados desde o estabelecimento das primeiras sociedades. A despeito de toda a engenharia desenvolvida sobre esses sistemas há mais de 6 milênios e com finalidades diversas (Julien 2002), é senso comum que as primeiras tentativas de compreensão dos mesmos estejam relacionadas ao papel vital das zonas de retenção de sedimentos sobre a fixação humana em porções específicas do globo terrestre, tais como os consagrados exemplos da Antiguidade Clássica: delta do Nilo e Mesopotâmia.

Algumas questões que justificaram no passado a busca pela compreensão do comportamento morfossedimentar dos rios, em suas zonas de agradação, ainda hoje permanecem muito atuais, como o entendimento dos condicionantes das inundações, da navegabilidade, das condições de pesca, da fertilidade das planícies e terraços aluviais, da estabilidade geotécnica dos depósitos, da ocorrência de bens minerais de alto valor agregado e da disponibilidade de materiais diversos para a construção civil.

Apesar da relação entre o comportamento dos rios e o modelado do relevo ter sido aceita a partir dos anos 1700 (Suguio e Bigarella 1979), apenas no fim da primeira metade do século passado houve o despertar para a necessidade de se converterem as variáveis que governam a ação fluvial em índices e coeficientes (p.ex., Horton 1945, Strahler 1952). A partir deste momento, apesar da nítida ruptura com a visão anterior, mais intuitiva, a percepção de que o número de variáveis que governam a dinâmica fluvial é grande e de que muitas delas são de difícil individualização e monitoramento suscitou várias dúvidas a respeito da previsibilidade do comportamento dos rios. Essa posição era advogada pelos trabalhos de natureza morfométrica e, 
consequentemente, por aqueles suportados por modelagem matemática.

Atualmente, tem-se percebido uma revalorização das descrições nos estudos morfossedimentares de rios, porém, com forte suporte em cartografia de detalhe e sensoriamento remoto (Kohler 2001). Outra mudança notada é o esforço para compreensão dos fenômenos de natureza tectônica e litológica, tidos como possíveis condicionantes da heterogeneidade do meio fluvial (Merrit \& Ellis 1994), em detrimento de variáveis de natureza numérica. Esta abordagem tem sido corriqueiramente referenciada nos trabalhos de morfotectônica (p.ex., Burbank \& Anderson 2001, Schumm et al. 2002, Schumm 2005).

Muitas técnicas de sensoriamento remoto fornecem informações acerca da geometria dos canais e de suas periferias (Drury 1998). Via de regra, se aceita que, por exemplo, zonas de drenagem não encaixada, bordejadas por patamares planos bem definidos, são consideradas áreas de preenchimento sedimentar ("vales de fundo chato"), motivadas por barramentos litológicos ou estruturais posicionados à jusante. Em oposição, as que drenam vales íngremes e estreitos ("vales em V") são atribuídas a zonas de ruptura dessas barreiras (Selby 1985).

Semelhantemente, áreas dominadas por depressões ovaladas (dolinas e uvalas) são tidas como produto da dissolução das rochas em subsuperfície e consequente abatimento (relevo cárstico) (Hugget 2003). Entretanto, características geológicas locais, ignoradas por boa parte dos sensores remotos, por serem observáveis apenas em campo e dificilmente convertidas em coeficientes numéricos, podem, num primeiro momento, mascarar os reais condicionantes dos padrões assumidos pelo sistema fluvial.

A bacia do rio Jequitaí apresenta grande geodiversidade, atestada principalmente por contrastes litoestruturais, que influenciam diretamente a fisiografia da região. Como a área só conta com mapas topográficos em escala 1:100.000 e cobertura geológica sistemática em escalas ainda menores, é notável a necessidade de se basear em dados de sensores remotos na tentativa de sanar a carência de informações sobre as variáveis que governam a atuação de seus sistemas fluviais.

No presente trabalho, os principais objetivos foram identificar, via sensoriamento remoto, um patamar morfológico de expressão regional ao longo da bacia; adensar os conhecimentos sobre o patamar identificado, observando em campo a existência de contrastes morfológicos (p.ex., anomalias de drenagem) dentro deste patamar, imperceptíveis na etapa anterior; efetuar o registro cartográfico detalhado de alguns segmentos do curso d'água principal contrastantes entre si; analisar a compilação da geologia regional, incluindo dados relacionados à tectônica cenozoica; determinar os condicionantes da instalação deste patamar, bem como dos possíveis contrastes morfossedimentares nele identificados.

LOCALIZAÇÃO A bacia do rio Jequitaíé afluente da margem direita do rio São Francisco, estando localizada na porção centro-norte de Minas Gerais, compreendida entre as UTM (23K) 8.142.531-8.017.162 (N) e 636.995-520.898 (E). A bacia verge de sudeste para noroeste e sua nascente se encontra na serra do Espinhaço, próximo à localidade de Curimataí. Essa mesma serra limita a bacia a leste. A sul e oeste estão os divisores de água da bacia do rio das Velhas e, a norte, os de três bacias de menor expressão areal (riachos do Barro e Canabrava e rio Pacuí).

As principais cidades da região são Buenópolis, Bocaiúva e Jequitaí e as vias de acesso mais importantes são as rodovias BR-135 e BR-365 (Fig. 1).

SINOPSE DA GEOLOGIA REGIONAL A bacia do rio Jequitaí não conta com cobertura geológica sistemática em escalas superiores a 1:250.000. Em linhas gerais, de acordo com Comig (2003), pode-se considerar que a mesma drena as coberturas do cráton do São Francisco, sendo marcante a presença das rochas do supergrupo homônimo, predominantemente metapelitos e metacalcários. Na região afloram também algumas unidades do Supergrupo Espinhaço, sobretudo na porção SE (Faixa Araçuaí) e na serra do Cabral, representadas na maioria das vezes por metarenitos. Além dessas unidades, estão presentes outras mais recentes, principalmente depósitos detrito-lateríticos e aluviões (Fig. 2).

Em termos estruturais, destaca-se na porção centro-sul da bacia uma anticlinal com caimento para norte, que representa a expressão estrutural da serra do Cabral, alguns lineamentos morfoestruturais e traços de falha indiscriminada, próximos à mesma serra. Além disso, de acordo com Penha (2001a), entre o Paleógeno e o Holoceno o regime tectônico da região teria sido compressivo e dominado por falhamentos transcorrentes de direção NW. Esses falhamentos teriam induzido o basculamento da serra da Água Fria para oeste e norte, e da serra das Porteiras para oeste e sul (Penha 2001b).

As principais evidências neotectônicas do regime supracitado incluem estrias de falha em lateritas, sedimentos terciários posicionados em diferentes cotas altimétricas, escarpas de falha balizando as chapadas, lagos com eixos maiores alinhados e o condicionamento estrutural, segundo os sistemas citados, de drenagens instaladas sobre sedimentos paleogênicos (terciários), a exemplo das capturas do rio Riachão (ou córrego Fundo) e do rio São Lamberto.

Os basculamentos condicionaram a implantação da calha do rio Jequitaí, cujo eixo coincide com a orientação do sistema neotectônico, que varia entre N60-90 ${ }^{\circ}$ W. Para Penha et al. (2005), este eixo se trata de um possível graben de idade paleocênica. Associado ao basculamento dos blocos em direção a este graben, teria ocorrido a captura das drenagens citadas anteriormente pelo rio Jequitaí (Fig. 3).

Ainda de acordo com Penha et al. (op. cit.), a ideia de reativação é corroborada por sondagens executadas pela Companhia de Pesquisa de Recursos Minerais (CPRM) e Petróleo Brasileiro S/A (Petrobras), além de dados sísmicos, que confirmaram a existência 

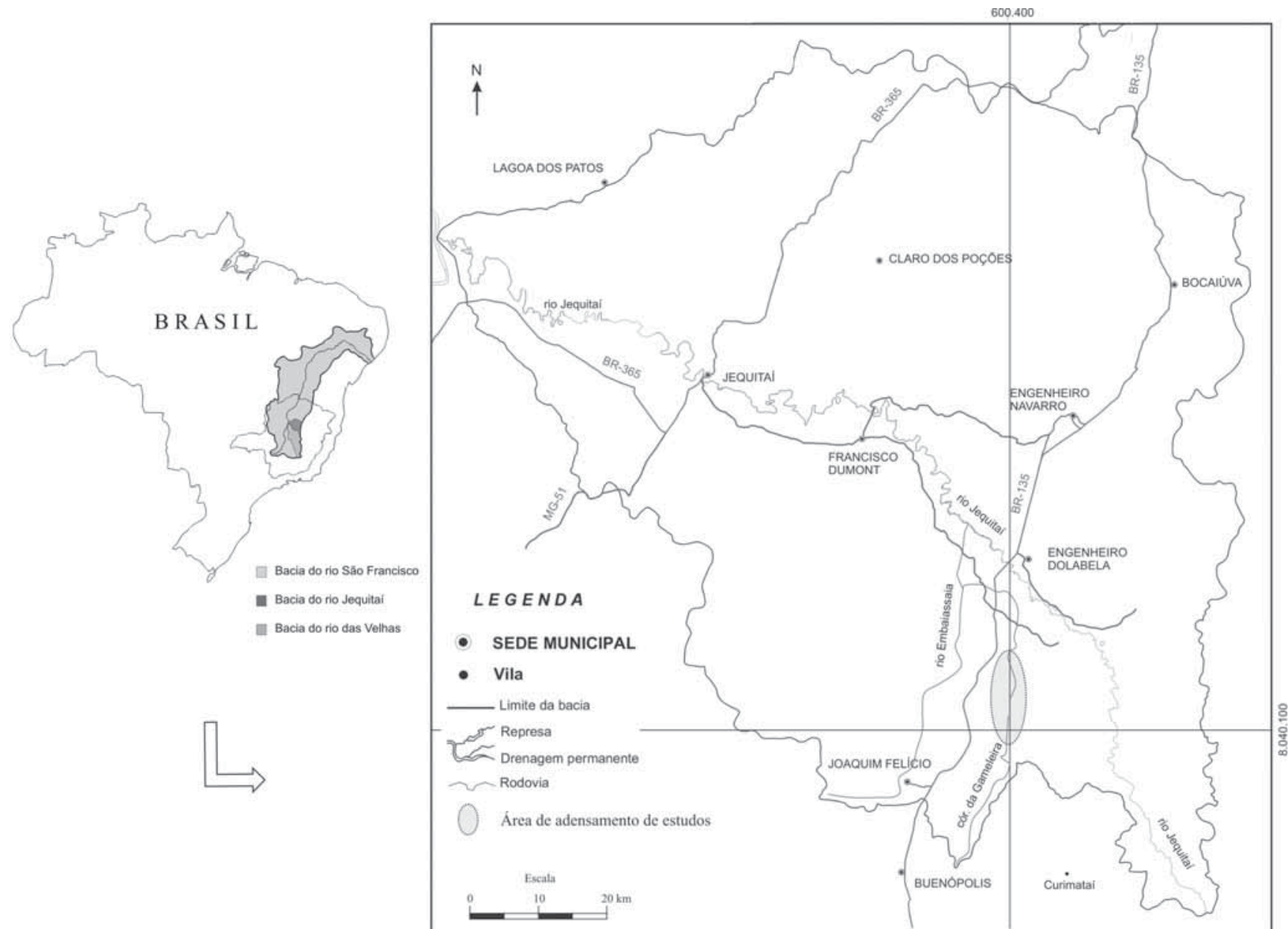

Figura 1 - Localização, vias de acesso e principais localidades da bacia do rio Jequitaí. Adaptado a partir de Cetec (2006).

de altos e baixos no embasamento, os quais poderiam ser interpretados como um sistema do tipo horst/graben, possivelmente reativado durante o Cenozoico. Hercos (2008) atesta a existência deste sistema na região em épocas pré-cenozoicas.

MATERIAIS E MÉTODOS No intuito de se identificarem patamares morfológicos ao longo da bacia do rio Jequitaí, foram utilizadas imagens SRTM (Shuttle Radar Topography Mission) (Miranda 2005). O uso dessas imagens se deve à disponibilidade gratuita das mesmas, somada à sua reconhecida qualidade e funcionalidade em estudos do meio físico (Crepani \& Medeiros 2005).

Os dados sobre o território brasileiro estão disponíveis para download no sítio da Empresa Brasileira de Pesquisa Agropecuária (Embrapa), que foi a responsável pelo seu processamento. Os mesmos são liberados de forma compatível com a articulação das folhas topográficas do Brasil em escala 1:250.000. As imagens utilizadas neste trabalho, que cobrem a área da bacia do rio Jequitaí, foram SD-23-Z-C, SE-23-X-A, SE-23-X-C e SE-23-Z-A.

Vários trabalhos de natureza geomorfológica têm citado a adoção de imagens SRTM (p.ex., Silva $\&$ Santos 2007) e isso se deve, dentre outros fatores, à possibilidade de processamento digital e à ênfase dada aos contrastes morfoestruturais, "desconsiderando" a cobertura de solo e vegetação, já que se tratam de dados obtidos por interferometria de radar de abertura sintética (InSAR).

De acordo com Grohmann et al. (2008), a resolução espacial é de $90 \mathrm{~m}$ e as precisões vertical e horizontal para a América do Sul são respectivamente 6,2 e $9 \mathrm{~m}$. Todos esses valores podem ser considerados bastante razoáveis para trabalhos que visem individualizar padrões de esculturação do relevo em escalas regionais.

Como as imagens, na verdade, tratam-se de modelos digitais de elevação (MDE), que por si só permitem a análise morfológica da bacia, o mosaico SRTM foi montado no software Global Mapper ${ }^{\mathbb{Q}}$, de forma a viabilizar a identificação preliminar dos principais patamares morfológicos da bacia estudada. No primeiro momento, as análises tiveram por base blocos diagramas e perfis topográficos gerados neste mesmo software.

Apesar de a etapa anterior ter viabilizado a identificação de alguns patamares com expressão regional, a geração de modelos de declividade, sobre as mesmas bases SRTM, permitiu que essas áreas fossem confirmadas e visualizadas com maior nitidez. Os modelos foram gerados no ArcScene ${ }^{\circledR}$ (pacote ArcGIS), a partir 


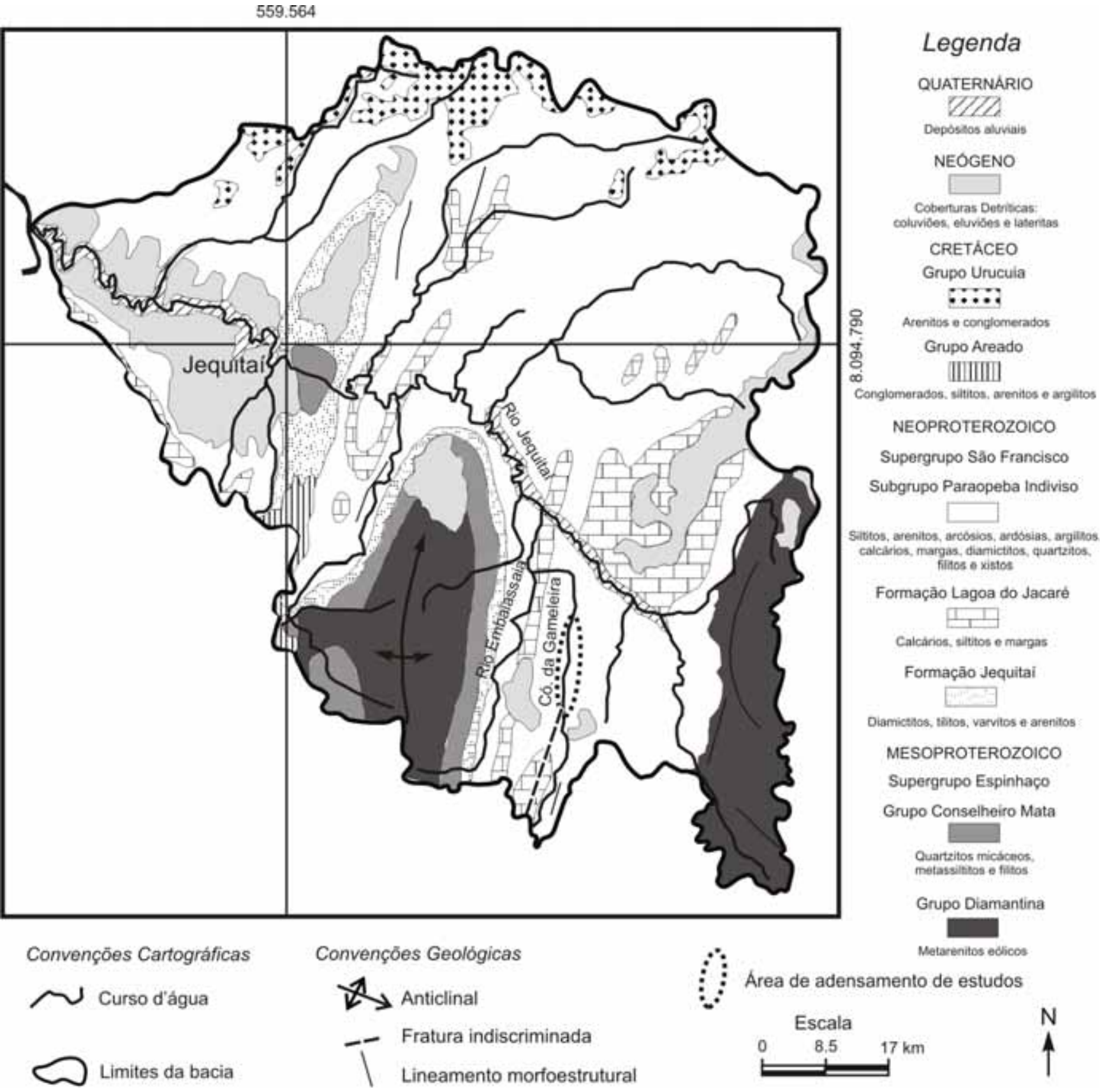

Figura 2 - Mapa geológico simplificado da bacia do rio Jequitaí, com as principais unidades litoestratigráficas presentes. Adaptado a partir de Moura (2000), Comig (2003) e CPRM (1985). Escala de levantamento da base 1:1.000.000.

de malhas triangulares irregulares (triangular irregular network - TIN) (Crosta 1993) e em compatibilidade com folhas topográficas com equidistância de curva de nível de $100 \mathrm{~m}$, otimizando a velocidade de processamento computacional.

Foram definidas 10 classes de declividade $(0-2$, 2-4, 4-6, 6-8, 8-10, 10-20, 20-40, 40-80, 80-100, 100$200 \%$ ), ilustradas por cores do branco (áreas planas) ao vermelho (áreas verticais), passando por tons de verde e laranja. O exagero vertical adotado foi de $5 x$.

Os patamares morfológicos foram identificados visualmente nas zonas onde ocorre brusca transição entre alta e baixa declividade. A rede de drenagem, em escala 1:250.000, foi extraída de Cetec (2006) e sobreposta aos modelos.

A figura 4A ilustra a forma com que a bacia foi visualizada a partir dos modelos gerados. Nela são salientados os principais acidentes geográficos da região.

Em campo, foi verificada a existência de contrastes morfológicos dentro do patamar selecionado. Os pontos de interesse foram fotografados e planimetricamente cartografados em escala 1:500, com intervalo médio de 2,5 m entre os pontos, de acordo com o disposto em Compton (1985). O equipamento adotado foi uma 
estação total Trimble ${ }^{\circledR} 3305 \mathrm{DR}$ (precisão linear de $3 \mathrm{~mm}$ +/- 2 ppm, precisão angular de $5 \mathrm{~s}$ e alcance de até 3.000 m) e o método adotado foi o da irradiação (Lahee 1952).

Para cada um dos pontos selecionados na etapa anterior, procedeu-se a descrição expedita da constituição granulométrica e petrográfica/mineralógica dos sedimentos do leito e margens (Nunnally 1967, Malarz 2005, Rengers \& Wohl 2007), utilizando-se cartela granulométrica, lupa e, para sedimentos grossos, um classificador de cascalhos (Lana 2004). O perfil de fácies sedimentares identificado foi descrito seguindo as técnicas apresentadas em Kondolf \& Piégay (2003).

O perfil e os mapas obtidos em campo foram vetorizados respectivamente no CorelDRAW ${ }^{\circledR} \mathrm{e} \mathrm{ArcMap}^{\circledR}$ (pacote ArcGIS) e, juntamente com o mapa geológico regional em 1:250.000 (CPRM 1985) e as informações sobre tectonismo cenozoico (Penha et al. 2005), permitiram que fossem feitas interpretações acerca da evolução morfossedimentar do patamar selecionado para adensamento de estudos.

RESULTADOS Dentre os patamares identificados na figura 4A (áreas em branco), motivos logísticos (facilidade de acesso e proximidade com um núcleo urbano - Joaquim Felício) fizeram com que aquele em que se encontra instalado o córrego da Gameleira fosse adotado como área de adensamento de estudos em campo (Figs. 1, 2, 3 e 4B).

Durante a etapa de campo, percebeu-se que ao longo de $15 \mathrm{~km}$, o patamar em questão apresenta grande heterogeneidade morfossedimentar. Em função dessas heterogeneidades, três pontos foram selecionados para adensamento e são descritos abaixo.

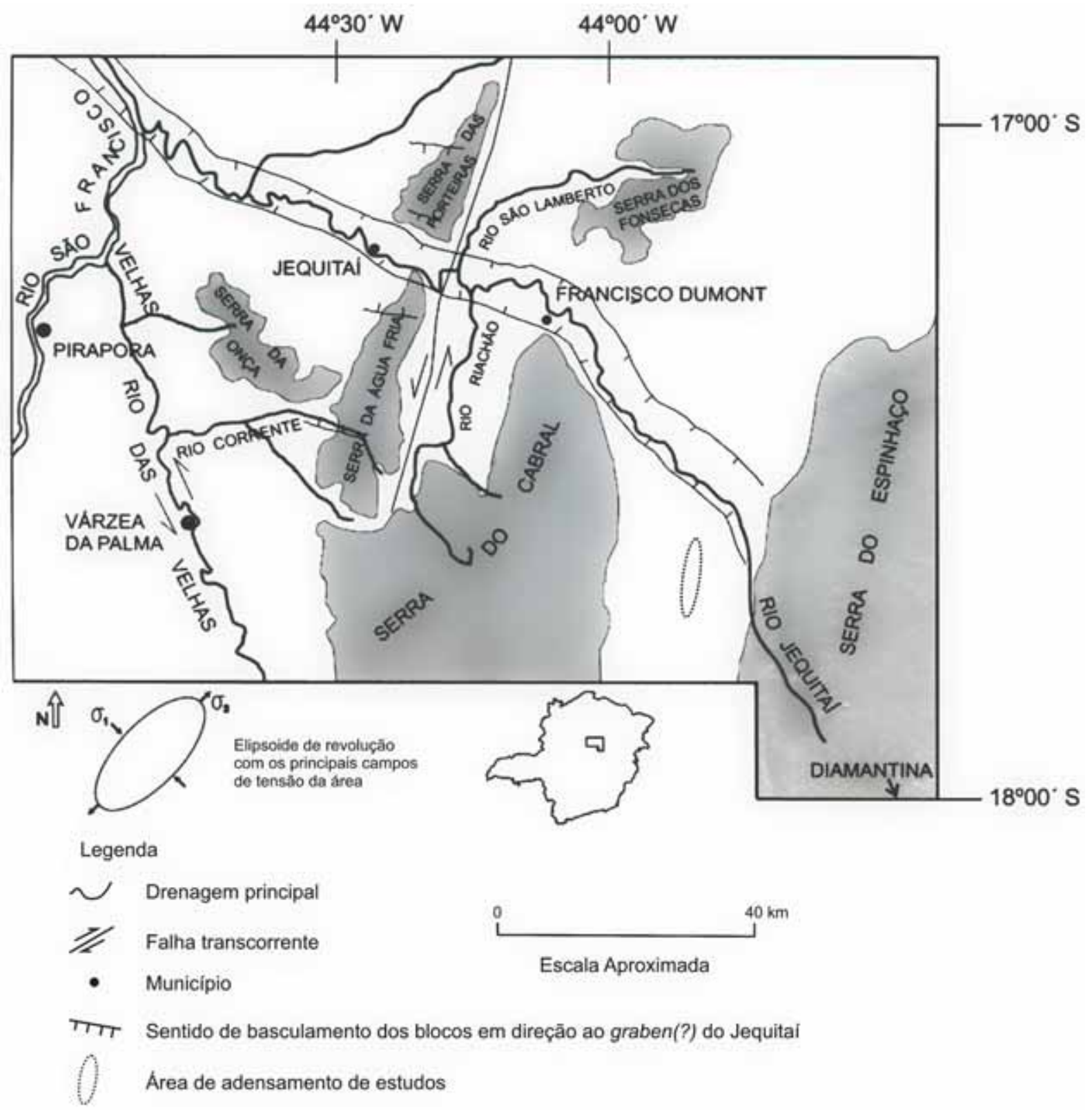

Figura 3 - Principais traços estruturais cenozoicos da bacia do rio Jequitaí. Modificado de Penha et al. (2005). 

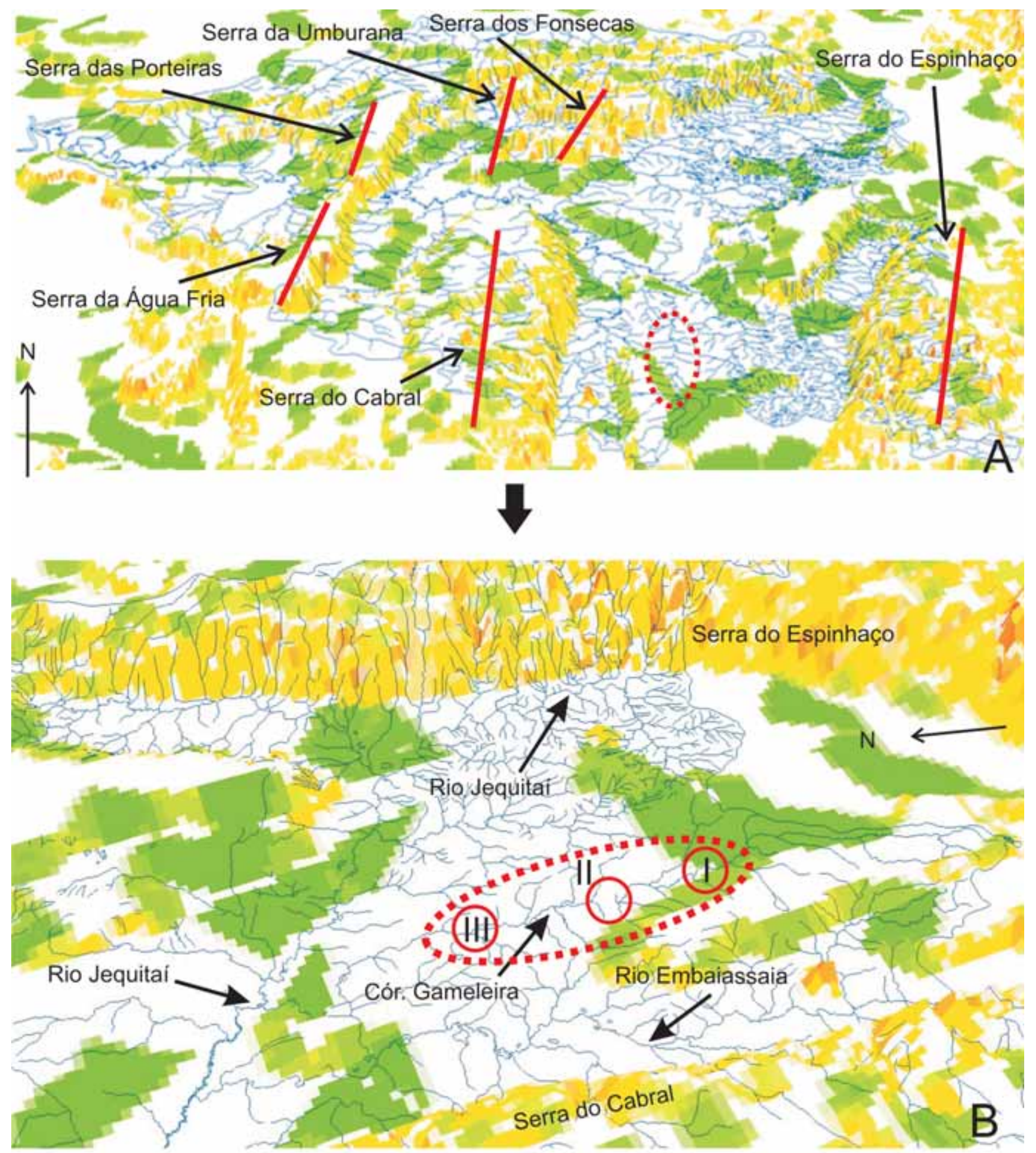

\section{Legenda}

Area de adensamento de estudo (figuras 3, 4 e 5)

$>$ Drenagem
$>$ Serras

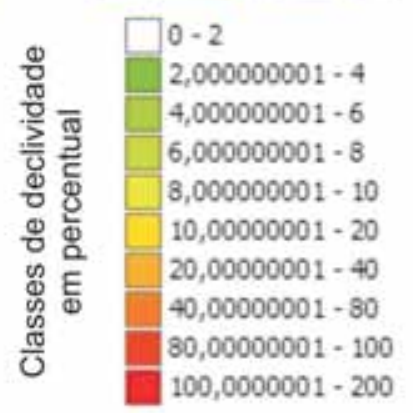

Figura 4 - Modelos de declividade. Em A, principais acidentes geográficos da bacia do rio Jequitaí. Em B, um zoom da área de adensamento de estudos. Rede de drenagem extraída de Cetec (2006). 

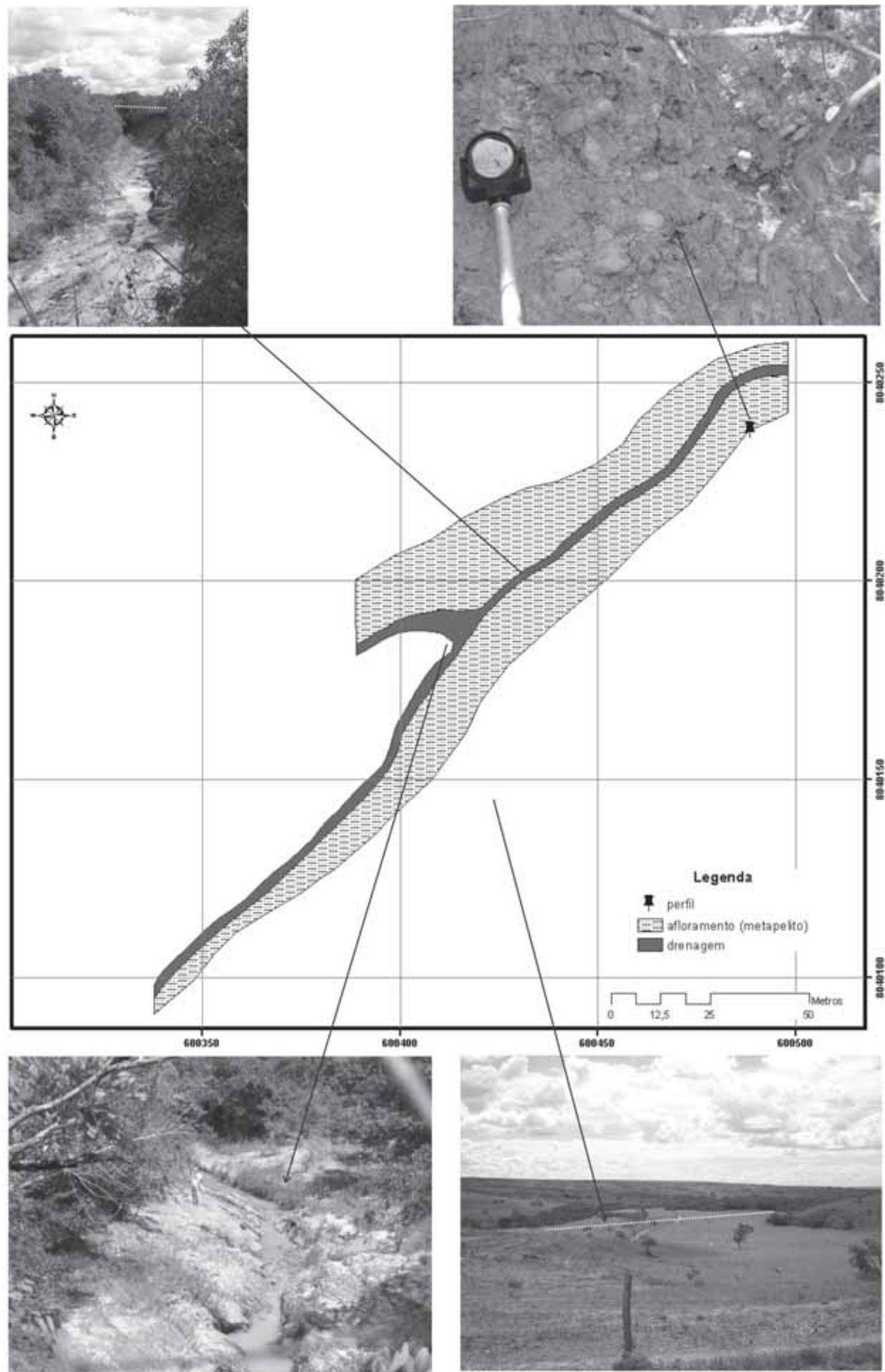

Figura 5 - Registro cartográfico e fotográfico do ponto I e imediações. A linha tracejada indica a superficie do patamar investigado. 
Ponto I Foi o segmento estudado mais a montante. O curso do córrego da Gameleira se encontra encaixado em metapelitos $\left(S_{0}=300 / 40\right)$, drenando concordantemente com um plano de fratura subparalelo ao acamamento $\left(\mathrm{S}_{\mathrm{n}}=300 / 48\right)$. O canyon possui aproximadamente $10 \mathrm{~m}$ de profundidade, sendo que os 2 a 2,5 m mais próximos à superfície topográfica são constituídos de depósitos sedimentares cascalhosos sobrepostos por depósitos arenosos. A figura 5 representa o mapa planimétrico do ponto em questão.

O segmento está instalado em uma área plana, limitada por colinas suaves, cujo pavimento é cascalhoso sendo que, em alguns cortes de estrada, é possível observar os pacotes ainda in situ (seixos grossos e subarredondados de quartzo e quartzito, por vezes imbricados para oeste) (Fig. 6).

Foi levantado um perfil de fácies sedimentares na margem direita do segmento em questão, próximo ao seu limite mais a jusante (Fig. 7). As fácies descritas foram:

F1 - o arcabouço é constituído de seixos muitos finos a grossos, subarredondados, de quartzo e quartzito. A matriz ocorre em proporção muito menor e compõe-se de areia média de quartzo, subarredondada. Os clastos estão imbricados para oeste e a estratificação plano-paralela observada no pacote é incipiente.

F2 - areias finas, mal selecionadas e subangulosas de quartzo, contendo clastos esparsos de quartzo e quartzito subarredondados e marcas de raízes. O pacote apresenta aspecto maciço.

Ponto II Trata-se de um segmento caracterizado por leito argiloso, não encaixado, levemente sinuoso e apresentando regime de fluxo inferior. As margens contam com uma franja de vegetação arbórea densa, instalada sobre um patamar colonizado por gramíneas, aparentemente uma planície de inundação. A profundidade da lâmina d'água em relação à superfície topográfica é da ordem de $1,5 \mathrm{~m}$.

No deslocamento até este ponto, a partir do anterior, notou-se que a diminuição do encaixamento da drenagem é gradual, assim como o aparecimento de alguns lagos próximos à margem direita do canal (Fig. 8). Além disso, foram observados afloramentos de metacalcário negro nas proximidades do ponto mapeado.

Pouco a jusante deste ponto, a drenagem superficial dá lugar a um charco. As características topográficas do patamar se mantêm, mas a área conta com a presença marcante de taboas (Tipha domingensis) (Fig. 9).

A morfologia observada no ponto II é apresentada na figura 10 .

Ponto III Este segmento está localizado a jusante da zona de charco citada no ponto anterior. A energia de fluxo é baixa, o leito é lamoso e raso, com margens colonizadas por vegetação arbórea. As imediações configuram uma área plana coberta por gramíneas. Um bloco de metacalcário escuro (semelhante ao citado no ponto II) foi encontrado junto à margem direita. A profundidade da lâmina d'água em relação à superfície topográfica é ligeiramente menor que a do ponto anterior.

A figura 11 ilustra as características morfológicas descritas neste ponto.

Com base nas observações de campo, foi possível estabelecer os perfis transversais esquemáticos dos pontos estudados e da área de charco. Os mesmos podem ser observados na figura 12 .

DISCUSSÕES E CONCLUSÕES Para balizar esta discussão, lançou-se mão do mapa geológico disponível em maior escala para a área de adensamento de estudos, que é a folha Pirapora em escala 1:250.000 (CPRM 1985) e perfis transversais dos pontos, obtidos a partir de dados SRTM (Miranda 2005) (Fig. 13). O intuito foi acrescentar informações ao mapa regional em escala 1:1.000.000 (Fig. 2) e confrontar os perfis com as sessões transversais constatadas em campo (Fig. 12).

De acordo com o mapa geológico, o segmento analisado do córrego da Gameleira drena as rochas do Subgrupo Paraopeba (metapelitos e metacalcários), estando por vezes confinado por pacotes sedimentares atribuídos a terraços antigos e depósitos coluviais.

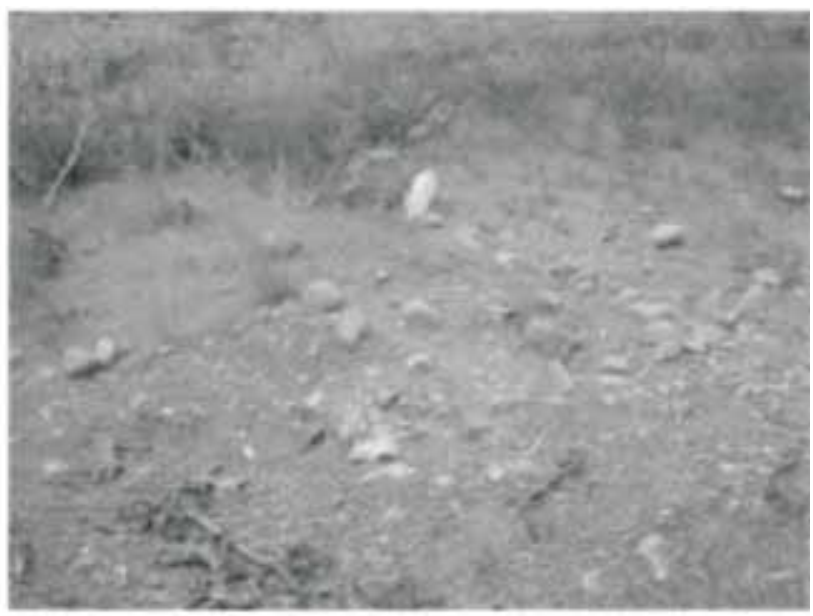

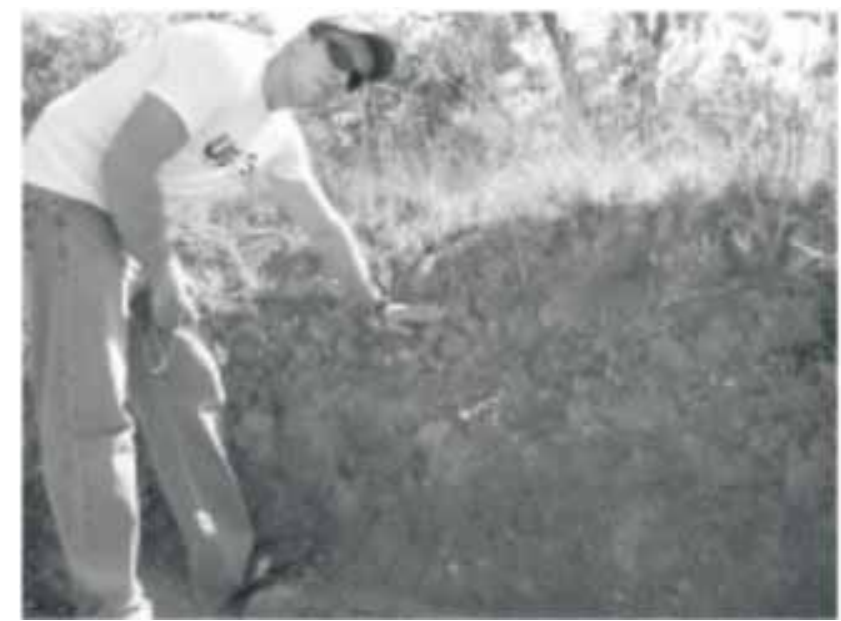

Figura 6 - Depósitos cascalhosos aflorantes nos cortes de estrada e na superfície das imediações do ponto I. 


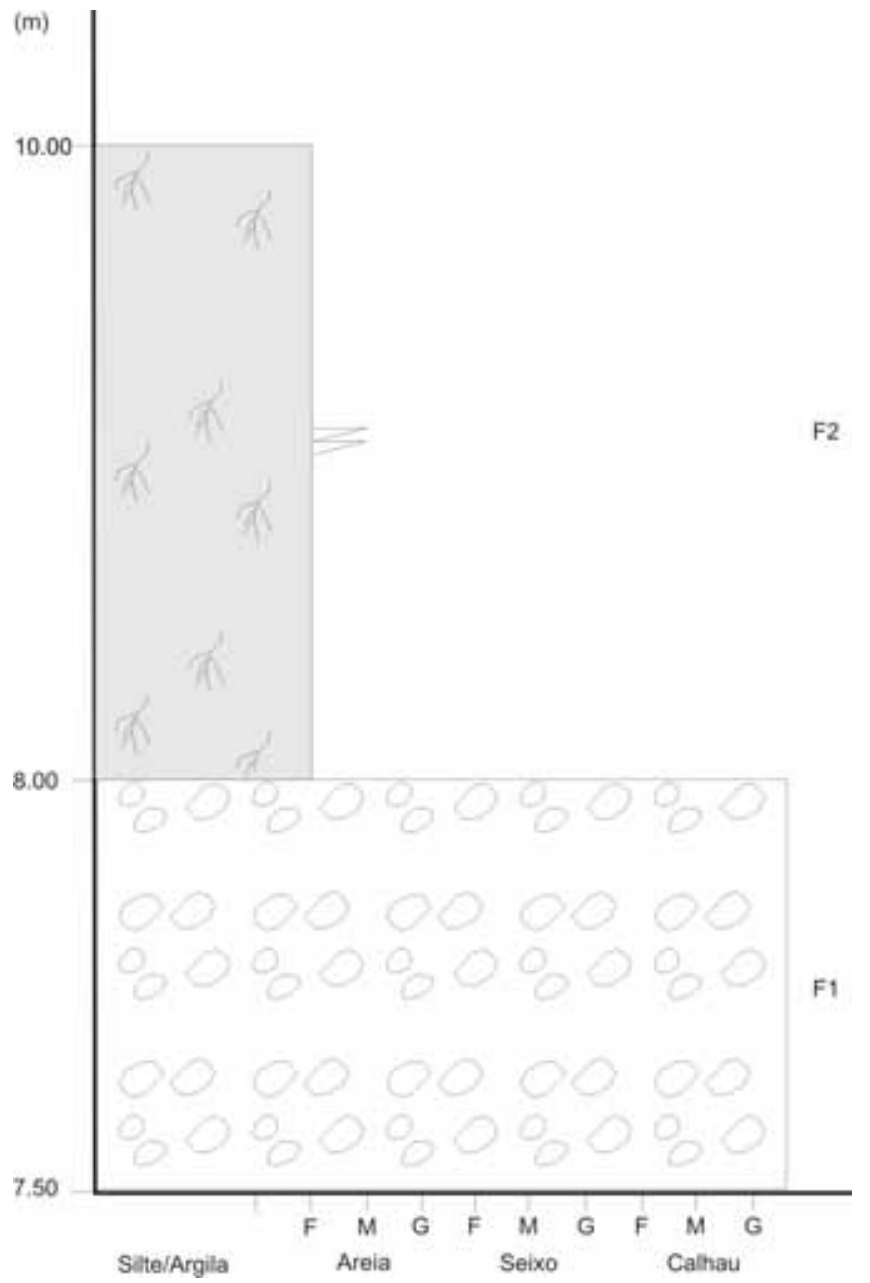

Figura 7 - Perfil de fácies sedimentares descrito na margem direita do ponto $I$.

O Subgrupo Paraopeba, segundo Castro (1997), é composto, da base para o topo, das formações Sete Lagoas (metacalcários), Serra de Santa Helena (metapelitos), Lagoa do Jacaré (metapelitos e metacalcários intercalados) e Serra da Saudade (metapelitos).

Em outros pontos da bacia do rio Jequitaí, quadros morfológicos muito semelhantes aos aqui descritos também foram identificados em diferentes cursos d'água (p.ex., rio Embaiassaia, rio São Lamberto etc.) (Lana 2010). No trabalho citado, constatou-se que a alteração drástica nos padrões morfossedimentares, ao longo de segmentos fluviais relativamente curtos, ocorre sempre em áreas onde aflora a Formação Lagoa do Jacaré (informação obtida em áreas com cobertura geológica em escala 1:100.000).

$\mathrm{O}$ ponto I se encontra a oeste de um plano de falha de direção NE-SW, ao passo que os pontos II e III estão sobre uma zona de preenchimento sedimentar aluvial (área de agradação).

No ponto I, o encaixamento da drenagem, que faz com que a lâmina d'água esteja a cerca de $10 \mathrm{~m}$ da superfície topográfica, acompanha o acamamento e um plano de diáclase que lhe é subparalelo. É provável que

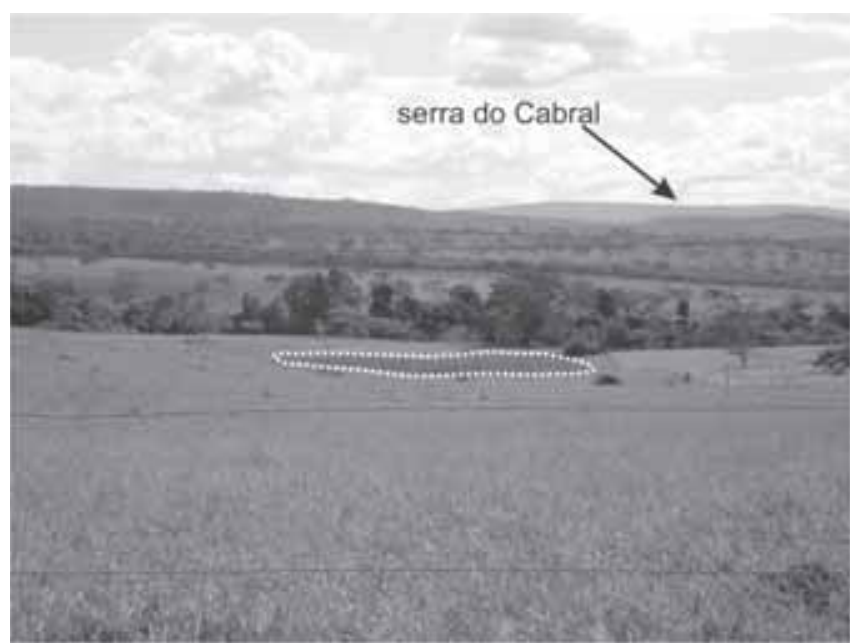

Figura 8 - Margem esquerda do córrego da Gameleira entre os pontos I e II. Notar a presença de um lago na porção central da foto e da franja de vegetação arbórea que bordeja o curso d'água. A serra do Cabral aparece ao fundo.

a diáclase possua relação com o plano de falha que se encontra a leste deste segmento (Fig. 13).

Além do encaixamento da drenagem ser naturalmente favorecido pela existência das diáclases, há de se considerar também o paulatino aumento da diferença de potencial, ocasionado pelo basculamento da região para norte, em direção à calha do rio Jequitaí, conforme advogado por Penha et al. (2005) (Fig. 3).

As fácies sedimentares descritas no ponto I (Fig. 7), e também observadas nos depósitos in situ das imediações (Fig. 6), remetem a um ambiente de leque aluvial (fácies F1 e F2 relacionáveis, respectivamente, às fácies Gm e Fm de Walker 1984), com área-fonte a leste. Com base nas dimensões da área em que afloram os pacotes sedimentares in situ e os pavimentos cascalhosos da

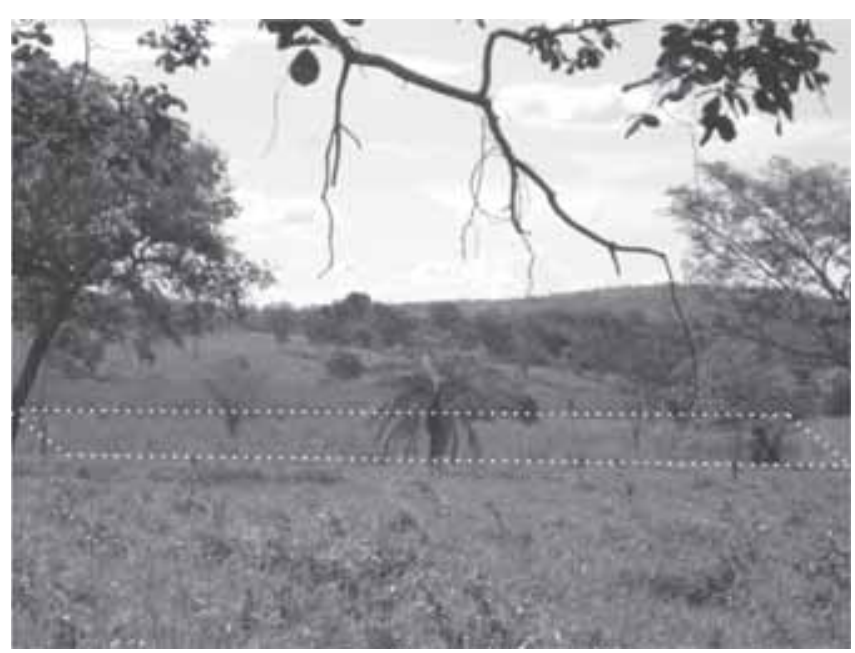

Figura 9 - Área em que a drenagem superficial do córrego da Gameleira dá lugar a um charco parcialmente colonizado por taboas. 


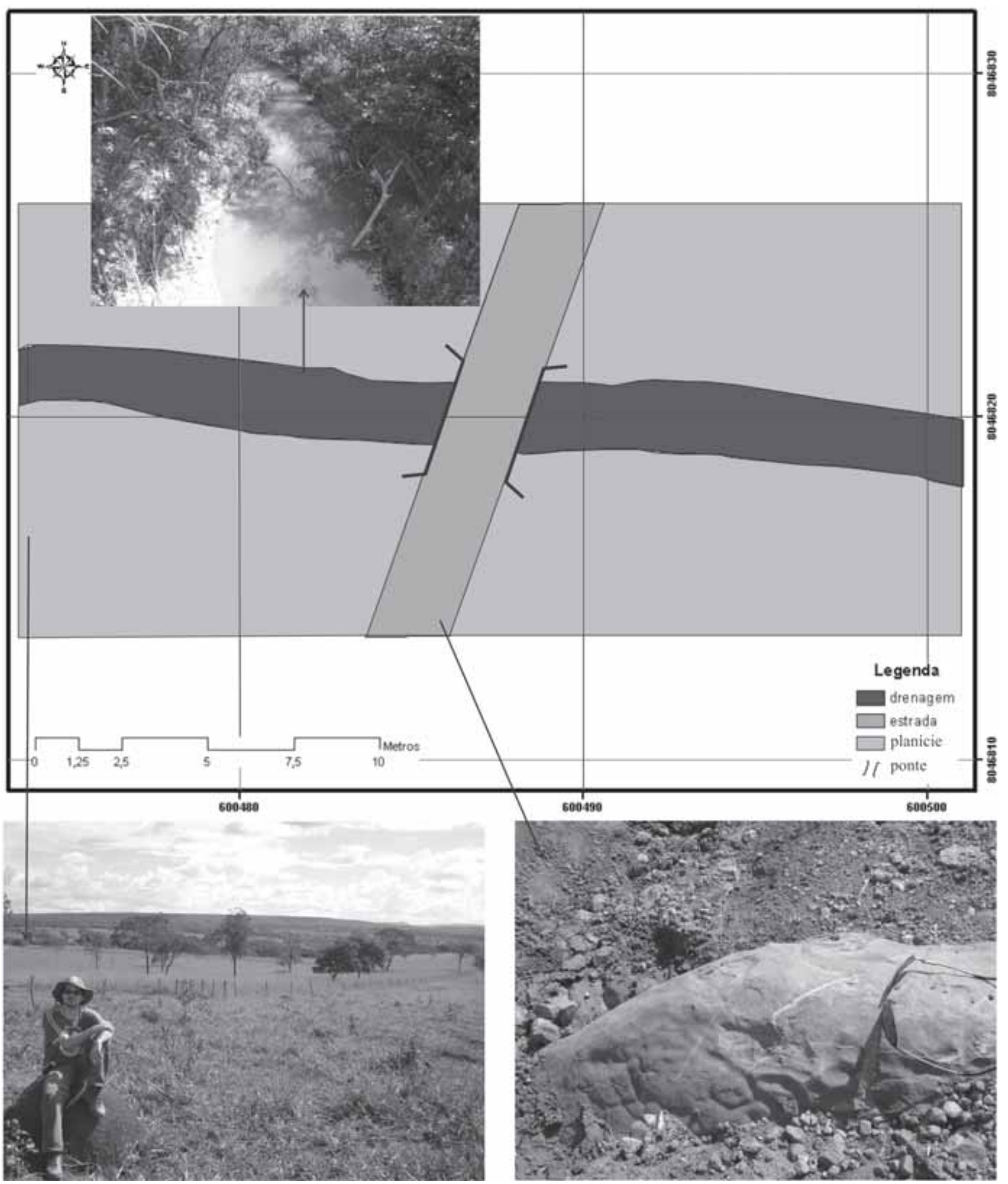

Figura 10 - Registro cartográfico e fotográfico do ponto II e imediações. A linha tracejada indica a superficie do patamar investigado.

região, englobando muito além dos três pontos mapeados, os referidos leques deveriam ter proporções regionais. Em outras palavras, todos os pacotes e pavimentos sedimentares identificados são incompatíveis com as condições hidrodinâmicas do sistema fluvial atual.
Os pontos II e III apresentam condições morfológicas e sedimentares bastante distintas das identificadas no ponto I. O leito argiloso e o pequeno desnível entre a lâmina d'água e a superfície topográfica demonstram que não se tratam de segmentos erosivos. 


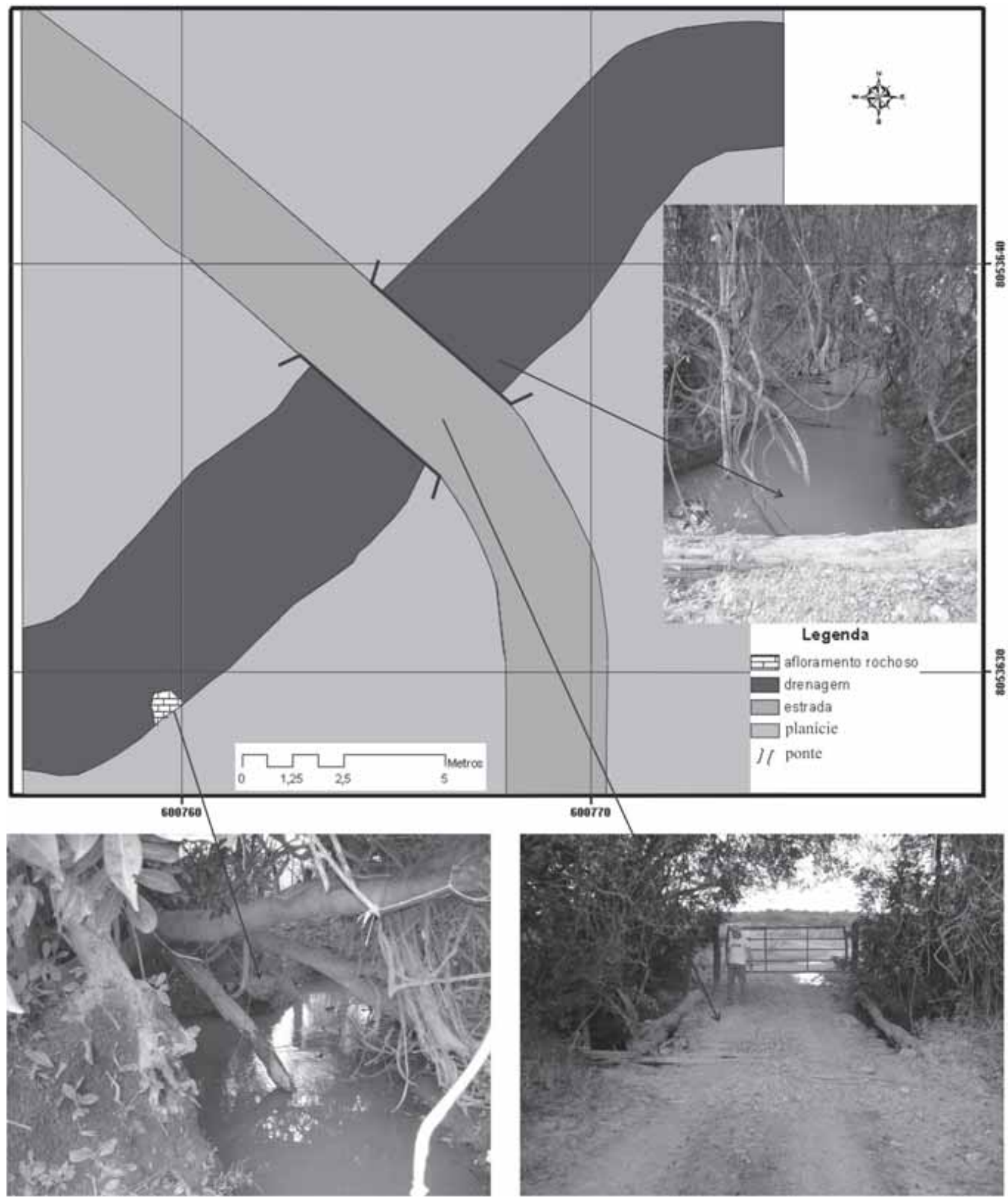

Figura 11 - Registro cartográfico e fotográfico do ponto III e imediações.

Ao longo do trajeto até esses pontos, a partir do ponto I, constata-se uma mudança morfológica sensível da faixa que margeia o córrego da Gameleira. O relevo se torna mais rebaixado e plano e alguns lagos são observados (Fig. 8). Esses fatos, somados aos afloramentos de calcário encontrados (Figs. 10 e 11) e à intermitência do canal entre os pontos II e III (Fig. 9), permitem inferir que a planície que margeia o canal, bem como os lagos presentes, se insere no contexto de solapamento de cavidades em ambiente cárstico. Porém, há de se considerar que as ocorrências de calcário são muito discretas e o abatimento ocorre de uma forma 


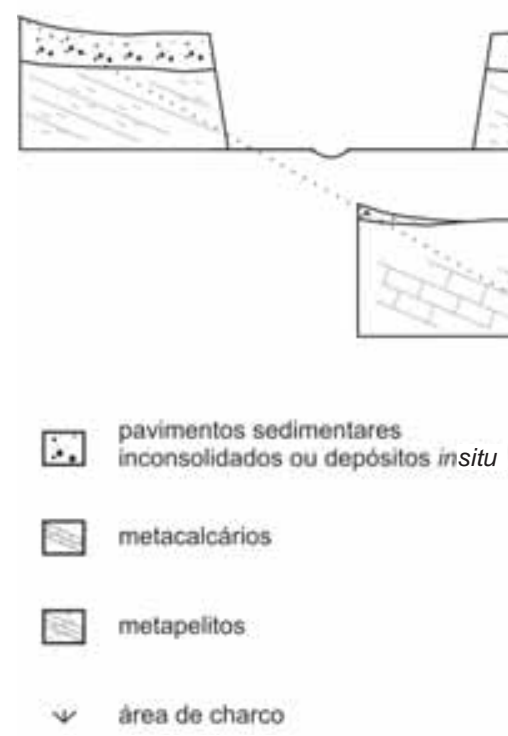

III

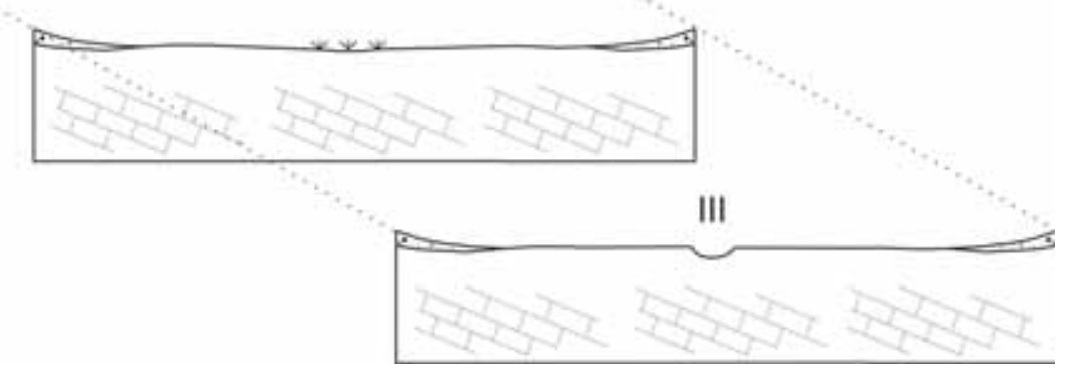

Figura 12 - Perfis esquemáticos dos pontos estudados e da zona de charco. No ponto I, o assoalho do canal é constituído de metapelitos, sobreposto por um pacote sedimentar; os pontos II e III drenam uma área composta provavelmente de metacalcário e os cascalhos aparecem na interface entre a planície e o sopé das colinas. O ponto do charco é marcado pela ausência do canal e a presença marcante de taboas em seu lugar.

contínua e assimétrica, acompanhando as margens do canal, numa configuração bastante distinta dos padrões clássicos apresentados na literatura para zonas de abatimento cárstico (dolinas e uvalas).

Apesar das constatações relatadas acima demonstrarem grande heterogeneidade morfossedimentar entre o ponto I e os demais, a unidade litoestratigráfica drenada é a mesma, de acordo com o mapa disponível (Fig. 13).

Em analogia com os dados obtidos por Lana (2010), é possível que a unidade do Subgrupo Paraopeba drenada pelo córrego da Gameleira seja a Formação Lagoa do Jacaré. Vale ressaltar o fato de alguns corpos desta formação já terem sido individualizados próximos à área de estudo em mapas de pouco detalhe (Fig. 2). Assumindo isso, e levando-se em conta a ocorrência de intercalações entre metapelitos e metacalcários nesta unidade, acredita-se que a espessura do nível de metacalcário, sotoposto ao metapelito na área do ponto $\mathrm{I}$, aumente à medida que se dirige para os pontos II e III.

Desta forma, é provável que, na região do ponto I, o córrego da Gameleira tenha se instalado sobre os depósitos de leque aluvial. Em função do ganho de energia associado ao basculamento anteriormente citado e também ao abatimento cárstico dos terrenos a jusante, o mesmo teria rompido estes depósitos até encontrar os planos de acamamento e diáclase, nos quais se encaixou gradativamente, mantendo traçado praticamente retilíneo.

Nos pontos II e III o córrego drena pacotes de alteração do metapelito e/ou metacalcário. O aumento na espessura do nível de metacalcários e a dissolução parcial destes teriam condicionado a instalação de dolinas (Fig. 8) e, principalmente, zonas assimétricas de abatimento. No ponto I, constatou-se em campo que os metapelitos não afloram em leitos horizontais, portanto, a existência de um patamar é mais um forte indício de que, apesar do nível carbonático não aflorar e ser supostamente mais delgado, a dissolução também tem efeitos sobre a esculturação da área. Caso contrário, quer pela presença dos leques aluviais, quer pela estruturação dos metapelitos, a conformação da área não seria um plano de bordas côncavas.

Planos de descontinuidade subparalelos à falha que é apresentada na figura 13 podem ter contribuído com o processo de abatimento, servindo de conduto para as águas superficiais. Nos locais onde fazem interseção direta com a superfície topográfica, eles favoreceriam a instalação de drenagens subsuperficiais (Fig. 14). Nas zonas em que o calcário ocorre em níveis muito delgados e/ou que ocorrem planos de diáclase com atitude distinta e que atingem a superfície, a drenagem afloraria na forma de ressurgências.

De acordo com os dados obtidos, é possível concluir que a área em questão apresenta um padrão de evolução morfossedimentar complexo, sobretudo quando se leva em conta a insuficiência da escala dos mapas geológicos disponíveis para a região de adensamento de estudos.

O trabalho demonstra, então, que em unidades litoestratigráficas de composição mista (intercalações indivisas) é praticamente impossível estabelecer uma relação fidedigna entre os padrões de evolução 


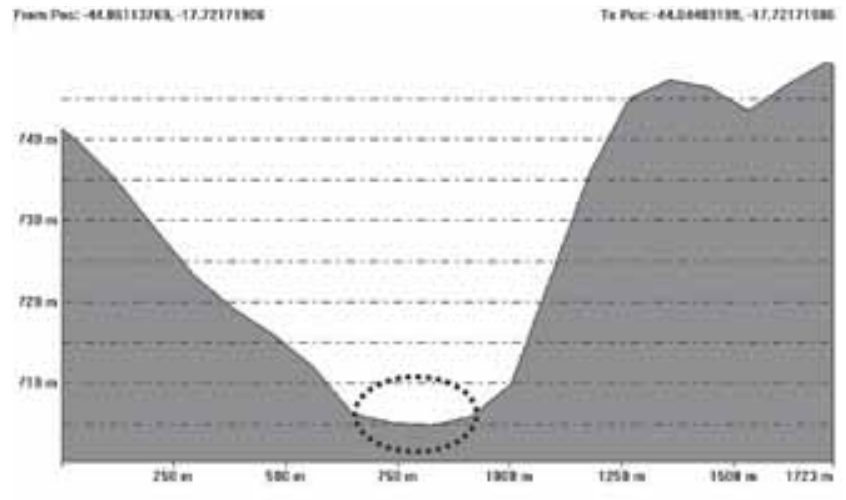

III

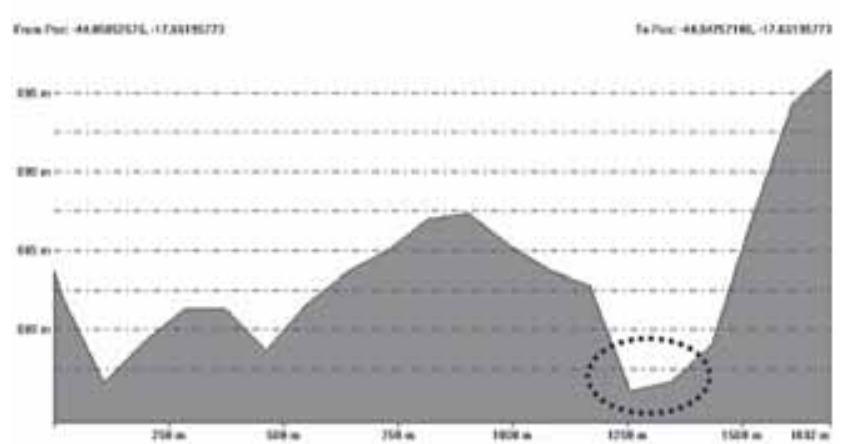

II

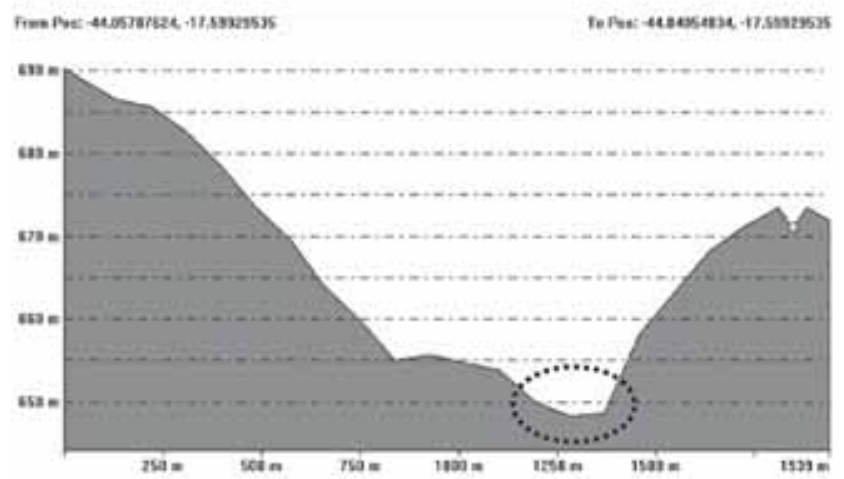

I

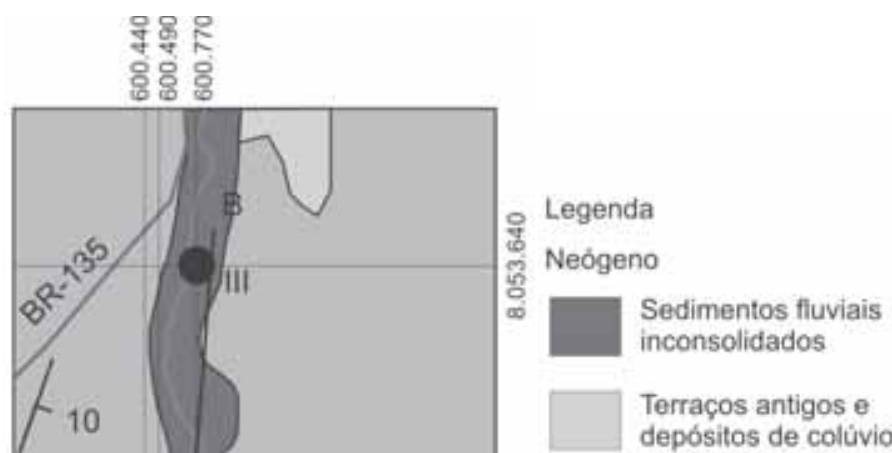

Neproterozoico

Metapelitos,

metacalcários e

metamargas

20

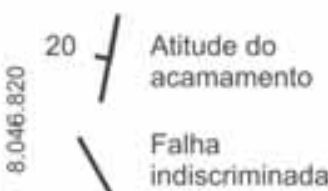

$\because$ Charco

Drenagem

Estrada

Posição dos

segmentos

estudados

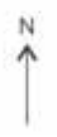

Figura 13 - Mapa geológico da área de adensamento de estudos. Modificado de CPRM (1985). À esquerda, são apresentados os perfis transversais de cada um dos pontos, obtidos a partir da imagem SRTM SF-23-X-C (Miranda 2005) no software Global Mapper ${ }^{\circledR}$.

morfossedimentar e a constituição litoestrutural do substrato. Além disso, contribuem com esta complexidade o encouraçamento da superfície por depósitos sedimentares mais recentes e a atuação de fenômenos tectônicos cenozoicos.

Os depósitos sedimentares apresentados nas figuras 2 e 13, provavelmente não são relacionados ao sistema fluvial, tendo em vista que nos pontos II e III, os dados apontam para uma evolução cárstica.

$\mathrm{O}$ exposto acima permite concluir que os planos observados, ao contrário de zonas de retenção sedimentar condicionadas por soleiras geomórficas ou barramentos estruturais, na verdade representam patamares de abatimento, encobertos por leques aluviais que só foram poupados do retrabalhamento em pontos específicos.

Os resultados alcançados demonstram que a geodiversidade da região é um agente complicador das predições morfossedimentares balizadas em dados cartográficos, cuja escala é incompatível com as particularidades dos objetos de estudo. Um exemplo claro é a incompatibilidade entre os perfis transversais obtidos por meio das imagens SRTM (Fig. 13) e o quadro real observado em campo (Fig. 12). O mesmo vale 


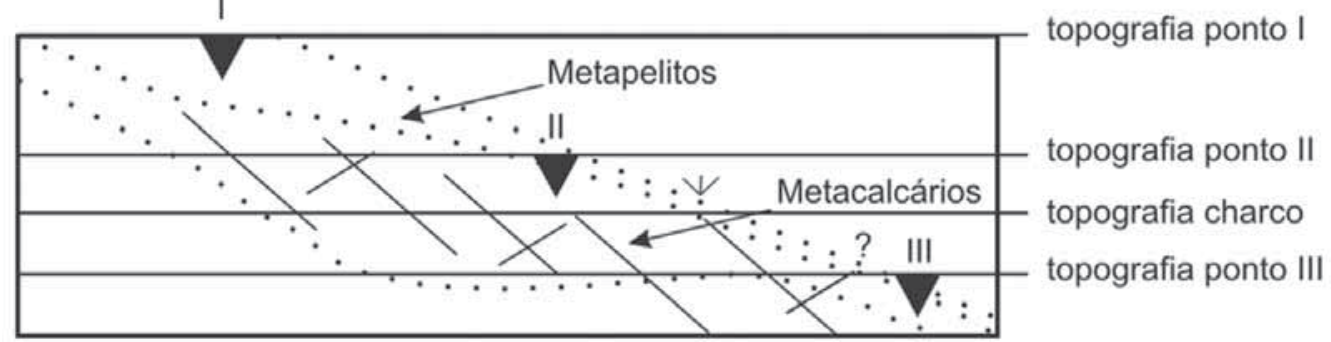

$\backslash$ fraturas

$\downarrow$ charco (sumidouro)

? ressurgência

canal

limite inferido

das litologias

From Pos: -44.05330489, -17.72781124

To Pos: $-44.04750282,-17.59581411$

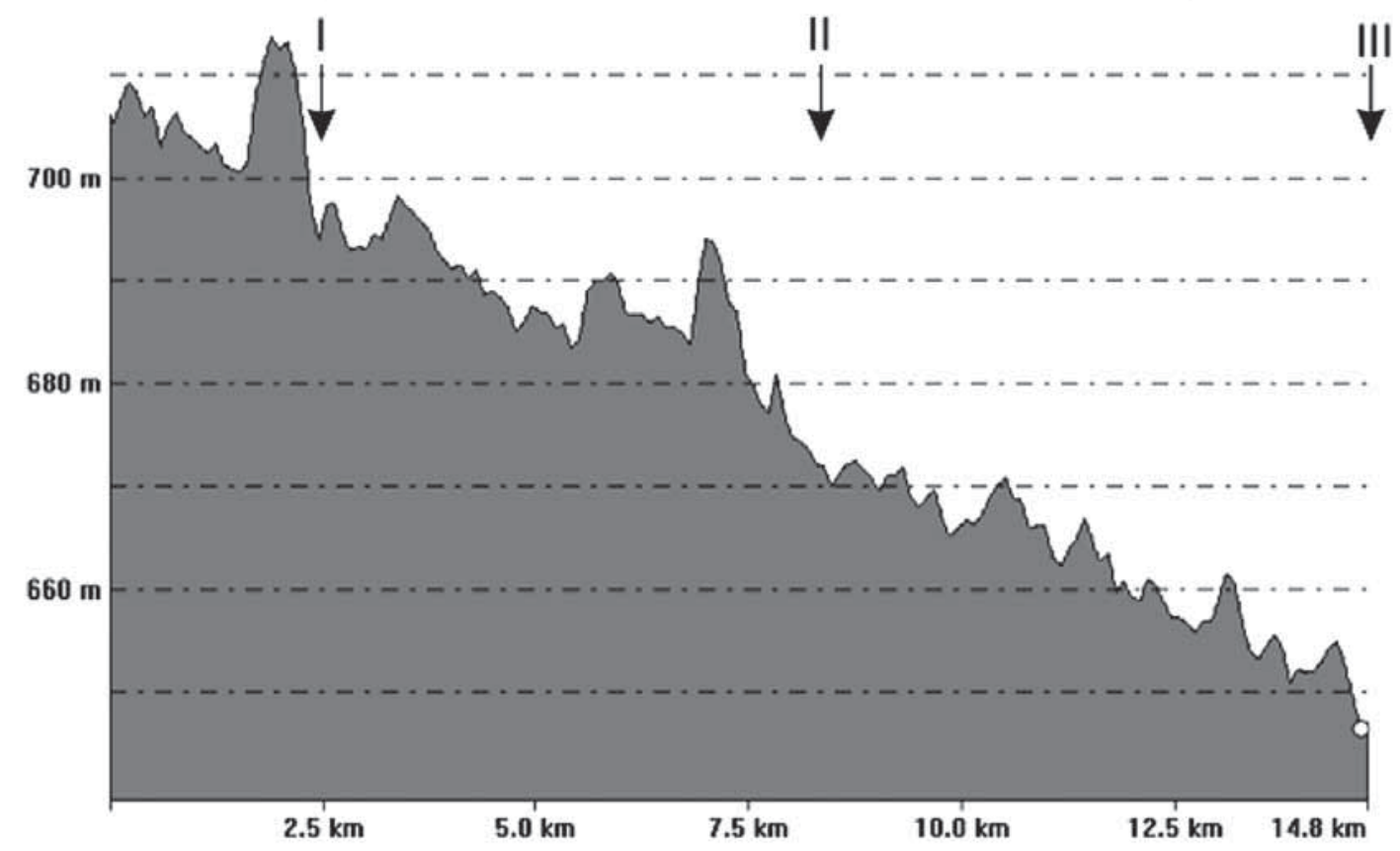

Figura 14 - Possivel quadro litoestrutural de subsuperficie, responsável pelo cenário morfossedimentar identificado ao longo do segmento investigado do córrego da Gameleira. O perfil topográfico longitudinal foi obtido no software Global Mapper ${ }^{\mathbb{B}}$, a partir da imagem SRTM SF-23-X-C (Miranda 2005).

para as modelagens que levam em consideração índices e coeficientes obtidos, boa parte das vezes, sobre dados coletados em cartas topográficas em escala de pouco detalhe e sem suporte em campo (p.ex., ordenamento e magnitude de drenagens e todos os dados daí resultantes).

\section{Referências}

Burbank D.W. \& Anderson R.S. 2001. Tectonic Geomorphology. New York, Wiley-Blackwell, 274 p.

Castro P.T.A. 1997. Os Conglomerados Associados ao Grupo Bambui na Porção Sudeste do Cráton do São Francisco: Sedimentologia, Estratigrafia e Implicações Tectônicas. Tese de Doutoramento, Instituto de Geociências, Universidade de Brasília, Brasília, 264 p.

CETEC (Fundação Centro Tecnológico de Minas Gerais). 2006. Estudo da Estrutura da Comunidade Ictiofaunística e dos Habitats Fluviais da Bacia do Rio Jequitai/MG, com Interesse para a Conservação. Belo Horizonte, CETEC, Relatório Técnico Final, 70 p.

COMIG (Companhia Mineradora de Minas Gerais). 2003. Mapa Geológico do Estado de Minas Gerais. Belo Horizonte, mapa geológico, escala 1:1.000.000.
Compton R.R. 1985. Geology in the Field. New York, Wiley, $398 \mathrm{p}$.

CPRM (Companhia de Pesquisa de Recursos Minerais Serviço Geológico do Brasil). 1985. Projeto Mapas Metalogenéticos e de Previsão de Recursos Minerais. Belo Horizonte, Folha Pirapora, escala 1:250.000.

Crepani E. \& Medeiros J.S. 2005. Imagens CBERS + Imagens SRTM + Mosaicos GeoCover LANDSAT em ambiente SPRING e TerraView: Sensoriamento Remoto e Geoprocessamento gratuitos aplicados ao desenvolvimento sustentável. In: INPE, Simpósio Brasileiro de Sensoriamento Remoto,12, Anais, 1 CDRom.

Crosta A.P. 1993. Processamento Digital de Imagens de Sensoriamento Remoto. Campinas, UNICAMP, $170 \mathrm{p}$. 
Drury S.A. 1998. Images of the earth, a guide to remote sensing. Oxford, Oxford University Press, 203 p.

Grohmann C.H., Riccomini C., Alves F.M. 2008. Aplicações dos Modelos de Elevação SRTM em Geomorfologia. Revista Geográfica Acadêmica, 2:73-83.

Hercos C.M. 2008. Arcabouço Tectono-Estratigráfico da Bacia do São Francisco nos Arredores das Serras da Água Fria e da Onça, Porção Centro-Norte do Estado de Minas Gerais. Dissertação de mestrado, Departamento de Geologia, Universidade Federal de Ouro Preto, Ouro Preto, $207 \mathrm{p}$.

Horton R.E. 1945. Erosinal development of streams and their drainage basin: hydrophysical approach to quantitative morphology. Geol. Soc. America Bulletin, 56(3):275-370.

Huggett R.J. 2003. Fundamentals of Geomorphology. Routledge, Grã-Bretanha, Routledge, 386 p.

Julien P. 2002. River Mechanics. Cambridge, Cambridge University Press, $434 \mathrm{p}$.

Kohler H.C. 2001. A Escala na Análise Geomorfológica. Revista Brasileira de Geomorfologia, 2(1):21-33.

Kondolf G.M. \& Piégay H. (eds.) 2003. Tools in Fluvial Geomorphology. Grã-Bretanha, Wiley, 688 p.

Lahee F.H. 1952. Field Geology. New York, McGraw-Hill, $883 \mathrm{p}$.

Lana C.E. 2004. Cartografia Integrada de Ecossistemas Lóticos (Fluviais) no Alto Curso do Rio das Velhas - MG. Dissertação de mestrado, Departamento de Geologia, Universidade Federal de Ouro Preto, Ouro Preto, 185 p.

Lana C.E. 2010. A Influência de Níveis de Base nas Características Morfossedimentares das Bacias dos Rios das Velhas e Jequitaí, MG. Tese de Doutorado, Departamento de Geologia, Universidade Federal de Ouro Preto, Ouro Preto, 227 p.Malarz R. 2005. Effects of Flood Abrasion of the Carpathian Alluvial Gravels. Catena. 64:1-26.

Merrits D.J. \& Ellis M. 1994. Introduction to Special Section on Tectonics and Topography. Journal of Geophysical Research, 99(B6):12.135-12.141.

Miranda E.E. de. 2005. Brasil em Relevo. Disponível em: http://www.embrapa.gov.br. Acessado em: 13/05/2006.

Moura L.C. 2000. Desenvolvimento de Metodologia para Recuperação de Dados Cartográficos para Utilização em Base de Dados Georreferenciados. Belo Horizonte, CETEC/FAPEMIG, mapas geológico, geomorfológico e de solos, escala 1:250.000.
Nunnally N.R. 1967. Definition and Identification of Channel and Overbank Deposits and their Respective Roles in Flood Plain Formation. The Professional Geographer. 19(1):1-4.

Penha U.C. 2001a. Geologia dos Conglomerados da Serra da Água Fria e dos Depósitos Diamantíferos da Região de Jequitai, $M G$. Tese de Doutoramento. Instituto de Geociências e Ciências Exatas, Universidade Estadual Paulista, $148 \mathrm{p}$.

Penha U.C. 2001b. Neotectônica e Diamante em Jequitaí MG. In: SBG, Simpósio de Geologia de Minas Gerais, 11, Anais, 1 CD-Rom.

Penha U.C., Karfunkel J., Angeli N. 2005. Diamondiferous Deposits in the Jequitaí Area (Minas Gerais, Brazil): a Consequence of Neotectonic Processes. Neues Jahrbuch für Geologie und Palaontologie - Abhandlungen, 236(12):207-224.

Rengers F. \& Wohl E. 2007. Trends of Grain Sizes on Gravel Bars in the Rio Chagres, Panama. Geomorphology, 83:282-293.

Schumm S.A., Dumont J.F., Holbrook J.M. 2002. Active Tectonics and Alluvial Rivers. Cambridge, Grã-Bretanha, Cambridge University Press, 292 pp.

Schumm S.A. 2005. River Variability and Complexity. Cambridge, Grã-Bretanha, 234 p.

Selby M.J. 1985. Earth's Changing Surface: an Introduction to Geomorphology. Oxford, Oxford University Press, $607 \mathrm{p}$.

Silva J.E.B. \& Santos P.R.A. 2007. A utilização dos modelos SRTM na interpretação geomorfológica: técnicas e tecnologias aplicadas ao mapeamento geomorfológico do território brasileiro. In: INPE, Simpósio Brasileiro de Sensoriamento Remoto, 13, Anais, p. 4261-4266.

Strahler A.N. 1952. Hypsometric (area-altitude) analysis and erosional topography. Geol. Soc. Am. Bull., 63:1117-1142.

Suguio K., Bigarella J.J. 1979. Ambientes de sedimentação sua interpretação e importância: ambiente fluvial. Curitiba, UFPR, 183 p.

Walker R.G. (ed.) 1984. Facies Models. Bathurst, Geoscience Canada, $317 \mathrm{p}$.

Manuscrito ID 15538

Submetido em 03 de dezembro de 2010 Aceito em 04 de outubro de 2011 